\title{
Dietary protein quality and proper protein to energy ratios: a bioeconomic approach in aquaculture feeding practices
}

\author{
Kifayat Ullah Khan ${ }^{1}$, Andressa Tellechea Rodrigues ${ }^{1}$, Cleber Fernando Menegasso Mansano ${ }^{3}$ \\ Daniel Monge de Almeida Queiroz ${ }^{1}$, Nilva Kazue Sakomura ${ }^{2}$, Rafael de Souza Romaneli ${ }^{1}$ \\ Thiago Matias Torres do Nascimento ${ }^{1}$ \& João Batista Kochenborger Fernandes ${ }^{1}$ \\ ${ }^{1}$ Aquaculture Center, São Paulo State University (UNESP), Jaboticabal, SP, Brazil \\ ${ }^{2}$ Department of Animal Science, Faculty of Agricultural and Veterinary Sciences \\ São Paulo State University (UNESP), Jaboticabal, SP, Brazil \\ ${ }^{3}$ Brazil University, Campus Fernandópolis , Fernandópolis, SP, Brazil \\ Corresponding author: Kifayat Ullah Khan (kifayat055@gmail.com)
}

\begin{abstract}
Supplementing high levels of dietary crude protein in the absence of amino acid balance and enough energy in fish diets may results in reduced growth, improper feed intake and poor protein utilization efficiency coupled with unviable feed costs and adverse environmental effects due to high nitrogen excretion. It is necessary to improve the dietary protein quality to avoid unnecessary nitrogen excretion, and the use of protein as an energy source by fish, quality and determine proper dietary protein to energy (DP:DE) ratios in order to maximize protein utilization efficiency. It will help the aquaculture sector to obtain better growth response at a low-cost and without any adverse environmental effects. In the present article, we have deliberated in detail the previous and ongoing researches about protein research in fish nutrition. Besides, we have made a comparison between two so far commonly used methods in protein research, i.e., the graded supplementation and dietdilution technique. According to the data presented here, is focusing on the formulation of balanced diets, the diet-dilution technique seems to be more accurate than the graded supplementation method. Thus, future studies should be focused on the use of diet-dilution technique along with proper dietary protein to energy ratios in order to formulate well-balanced diets. These attempts will significantly improve the protein and energy research in aquaculture nutrition. Moreover, feed industries will become able to formulate biologically balanced and environment-friendly diets at a low cost.
\end{abstract}

Keywords: feed formulation; effective protein to energy ratios; better biological response; low-cost balanced diets; aquaculture nutrition

Dietary protein is an essential but most expensive nutrient in fish diets that directly affect fish growth, feed intake and feed costs (Halver \& Hardy, 2002; Lee et al., 2002). Its insufficient amounts in diets cause reduced growth and unregulated feed intake, while its excessive amounts make the diet unbalanced and may result in extra feed costs, nitrogen excretion and aquatic pollution (Alam et al., 2008). Therefore, it is necessary to improve the protein quality of diets in order to achieve balanced diets and control the increasing feed costs and aquatic pollution.

Protein requirement is closely related to energy amounts in diets due to the protein-sparing effect of dietary energy (Ai et al., 2004). The supplementation of high protein with insufficient energy is responsible for decreased protein utilization efficiency (Robinson \& Li, 1997; Ai et al., 2004). Since, protein should be used only for tissue synthesis rather than as a source of energy (Walton \& Cowey, 1982; Li et al., 2012). The supplementation of the proper dietary protein of good quality coupled with proper energy is a critical factor for obtaining optimum growth, feed intake and maintenance of fish (Lemos et al., 2014).

In protein requirement research, the main problem is the use of unbalanced diets (Kesamura et al., 1982; Silva \& Perera, 1985; Teshima et al., 1985; Wang et al.,

Corresponding editor: Jesús Ponce-Palafox 
1985a,b; Siddiqui et al., 1988). High protein diets need adequate energy to be metabolized properly, and it has been recommended as an important approach to utilize better the available protein by enhancing the protein utilization and reduces the extra supplementation of nitrogen and consequently the aquatic pollution (McGoogan \& Gatlin, 1999). Diets with amino acid balance are usually known as well-balanced and such diets should be provided with proper energy in order to avoid the use of amino acids as a source of energy. For this purpose, dietary lipids are usually considered good sources of energy and essential fatty acids which are necessary for proper growth and development of fish. The use of lipids as compared to carbohydrate as a source of non-protein energy is usually considered more efficient because it is an energy-rich nutrient and is happily metabolized by fish (NRC, 2011). Proportionally more of the dietary amino acids oxidize and less partition into synthesis when diet with a higher protein to energy ratio offer to cod which explains the lower anabolic stimulation of cod. Thus, it is notable that omnivorous and herbivorous fish can utilize a broader range of diets than carnivores (Carter et al., 1994).

\section{Dietary protein quality}

Most of the previous literature (Table 1) is based on graded supplementation methodology using crude values for the formulation of diets and thus, showing higher dietary protein and energy requirements for several fish species. The higher protein and energy requirements may be due to the use of crude protein (lack of amino acids balance) or poor quality protein ingredients (Gous et al., 2018). Diets with poor quality protein sources and without amino acid balance and insufficient energy are usually considered unbalanced (Wethli et al., 1975). Sometimes while using high protein contents, the energy may become a limiting factor which results in the determination of improper protein requirements (Gous et al., 2018).

In the aquaculture industry, the formulation of economically and biologically viable and environmentfriendly diets is getting popularity. In this regard, researchers and feed industries are working together on different feed approaches and techniques in order to minimize the use of high protein levels by improving the dietary protein quality and energy levels. So far, two types of techniques have been used in animal research (Fisher \& Morris, 1970; Gous \& Morris, 1985) and fish nutrition (Abboudi et al., 2007; Liebert \& Benkendorff, 2007). One is the graded supplementation technique which describes the graded supplementation of synthetic amino acid/protein to a basal diet deficient in amino acid/protein. The disadvantage of this method is that a systematic change occurs in amino acid balance in

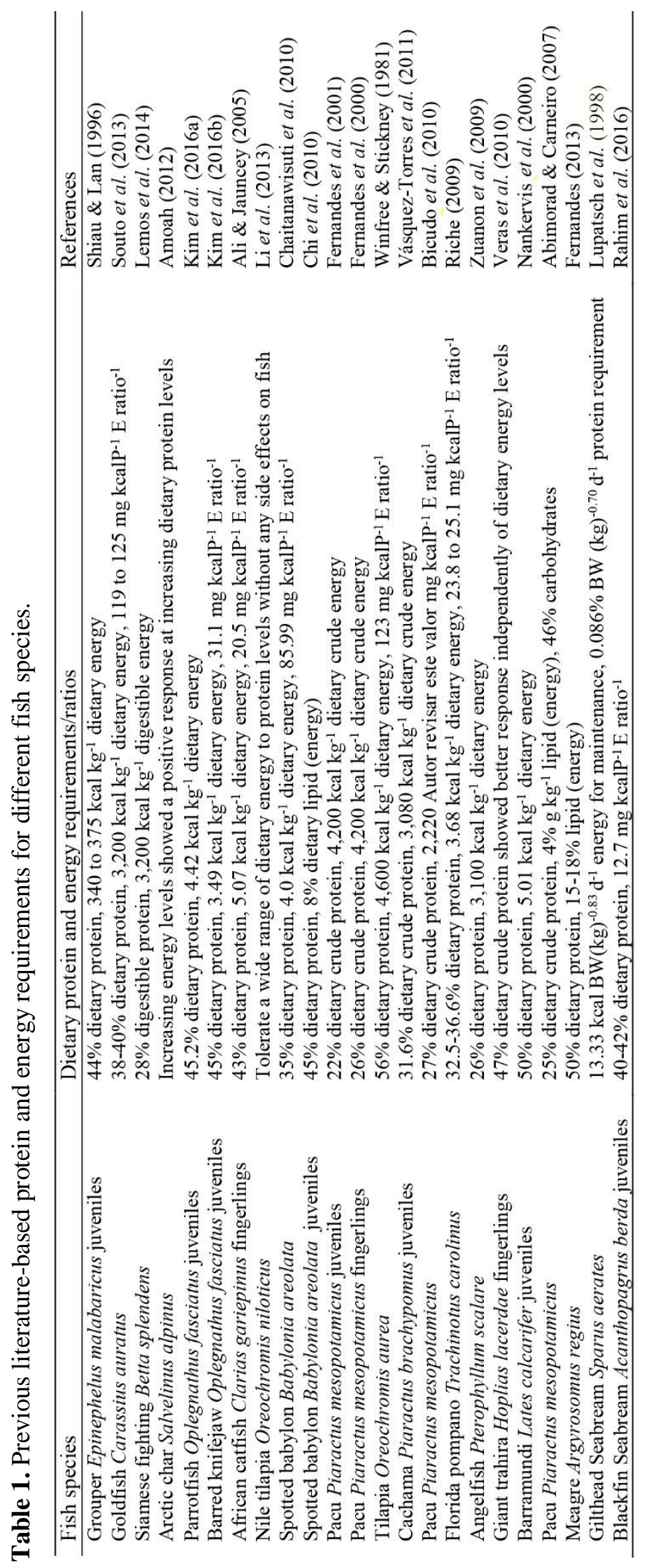


different dietary treatments which may affect the growth response and feed intake (Fisher \& Morris, 1970; Gous \& Morris, 1985). The other problem is faced during the determination of amino acid requirements for maintenance where amino acids to be tested usually used at low amounts than their optimum requirement for growth. Diets with too much synthetic amino acid (AA) are unable to maintain fish growth as they restrict the feed intake (Cowey, 1992).

The second is diet dilution technique which, for the first time, was established for the evaluation of growth responses to methionine intake in laying hens (Fisher \& Morris, 1970). The same method with some modifications was then used by Pilbrow \& Morris (1974) to determine laying hen response to dietary lysine intakes. Freeman (1979) used it for the determination of tryptophan requirement in chicks. Similarly, Gous \& Morris (1985) used the same technique for evaluating the response of broiler chickens to increasing levels of lysine.

Later on, it was also tested in fish species like in Atlantic salmon (Salmo salar L.) to determine its threonine requirement for maintenance by Abboudi et al. (2007) and in Oreochromis niloticus to determine lysine requirements by Liebert and Benkendorff (2007). This technique is based on the formulation of two basal diets, a high protein diet and the protein free or low protein diet (Fisher \& Morris, 1970). The high protein diet usually contains all essential amino acids in excess than its requirement, and the low protein diet provides an amount of EAAs less than their requirement. It is based on the hypothesis that AA utilization is independent of the dietary protein level and it avoids the problem of the change of amino acid balance in successive dietary treatments. Moreover, the high-protein and low-protein diets supply the dietary amino acid ratios on the basis of protein-bound AA. Therefore, it also avoids the problem regarding the restricted feed intake and low utilization of diets provided with too much synthetic AAs, which has been reported as an important limitation of the graded supplementation method (Hauler and Carter, 2001). Thus diets formulated by the dilution technique significantly improve the feed intake and maintain proper growth (Abboudi et al., 2007). This method needs to be further tested in fish nutrition, in order to decide which method is accurate. However, on the basis of the above-mentioned facts and results, diet dilution technique appears more valid than the graded supplementation method as it makes possible the development of well-balanced diets and also provides an excellent design to study the amino acid requirements for maintenance (Fisher \& Morris, 1970; Gous \& Morris, 1985; Halver \& Hardy, 2002; Abboudi et al., 2007; Liebert \& Benkendorff, 2007).

\section{Dietary protein to energy (DP:DE) ratios}

Optimum protein requirements cannot be determined until sufficient energy is provided in the diet. On the other hand, the animal will use part of the dietary protein as an energy source which may lead to the assessment of inaccurate protein requirements. Thus, the graded supplementation approach is somewhat controversial in fish nutrition since the proper ratio between dietary protein and energy is essential to be maintained during the formulation of diets ( $\mathrm{Li}$ et al., 2013). Diets supplemented with high protein, but low energy levels, restrict the feed intake and result in reduced performance of animals including fish (Morris et al., 1987; Gous et al., 1990; Li et al., 2013). Such a relationship between protein and energy has been documented in several animals such as pigs and broilers (Campbell et al., 1985; Morris \& Njuru, 1990).

According to Kyriazakis \& Emmans (1992), the protein utilization efficiency is affected negatively by the abnormal protein to energy ratios. The importance of proper dietary protein to energy ratio in the formulation of fish diets has been reported in several previous pieces of research (Webster et al., 1995; Hernández et al., 2001; Ai et al., 2004; Li et al., 2013). These ratios may vary due to several factors such as fish species, size, growth phase, dietary protein source, amino acid profile, environmental conditions, experimental design and feeding habit (Ai et al., 2004; Wang et al., 2013).

The optimum dietary protein requirement and P:E ratios have been determined for several fish species (Tacon \& Cowey, 1985; Teshima et al., 1985; Hepher, 1988; Moon \& Gatlin, 1991; Okorie et al., 2007; NRC, 2011). It has been documented that the use of proper dietary protein: energy ratios (mg protein $\mathrm{kcal}^{-1}$ ) had improved the growth and feed utilization efficiency of channel catfish, Ictalurus punctatus (Garling \& Wilson, 1976), Indian major carp, Labeo rohita (Das et al., 1991), Nile tilapia, Oreochromis niloticus (El-Sayed \& Teshima, 1992), red hybrid tilapia, Oreochromis sp. (Santiago \& Laron, 1991), blue tilapia, Tilapia aureus (Winfree \& Stickney, 1981), Asian seabass, Lates calcarifer (Catacutan \& Coloso, 1995), Korean rockfish, Sebastes schlegeli (Kim et al., 2004), bagrid catfish, Pseudobagrus fulvidraco (Kim \& Lee, 2005), Japanese eel, Anguilla japonica (Okorie et al., 2007), and Persian sturgeon, Acipenser persicus (Mohseni et al., 2013).

If proper DP:DE ratios are not provided in diets, then amino acids which are the building blocks of protein are utilized by fish as an energy source. Consequently, the balance between protein and energy is lost and brings high nitrogen releases into the aquatic environment due to the deamination of surplus amino 
acids. Low protein to energy ratios may reduce the growth performance due to greater metabolic need of energy to eliminate extra nitrogen and thus result in the deterioration of water quality, which is not suitable for a healthy aquatic environment (Catacutan \& Coloso, 1995; Tibbetts et al., 2000; Alam et al., 2008). While high protein to energy ratios perhaps cause an increased lipid deposition in the body and reduce the feed intake and may lead to the scarcity of some nutrients (Cho, 1992). Therefore, the use of proper protein to energy ratios plays an important role in the formulation of practical diets in the fish industry.

Some fishes efficiently utilize dietary nutrients over a wide range of dietary protein to energy (DP:DE) ratios and energy quantities (Carter et al., 1994). They attempt to improve their body energy status as compared to maximizing growth at the expense of lipogenesis patenting from dietary protein without inducing any harmful effects on the proximate composition or performance. The extra energy deposition may be used for seasonal, migratory or maintenance purposes. Moreover, low DP:DE ratios but high energy levels can improve the feed conversion ratio (FCR) of fish. The positive link between dietary energy and FCR has been reported in various aquatic species (Hillestad \& Johnsen, 1994; El-Mowafi et al., 2010; Ekmann et al., 2013) when growth was not restricted via dietary protein level. Similar results were obtained for gilthead sea bream which has shown an efficient utilization of diets with low DP:DE ratios but higher energy levels (Ekmann et al., 2013). This information may be important and could be taken into consideration in future protein and energy requirement research.

\section{Introducing well-balanced diets in the aquaculture sector}

For obtaining maximum growth response, it is necessary to increase the feed intake which can be improved only by the use of balanced diets (Lovell, 1989; Cho et al., 2005). Thus, proper attention is needed about the dietary protein quality and the dietary DP:DE ratios in order to establish well-balanced diets. On the other hand, improving the protein quality and using proper $\mathrm{P}: \mathrm{E}$ ratios make it possible to formulate well-balanced diets at low cost which are biologically effective and environment-friendly (Catacutan \& Coloso, 1995; Martino et al., 2002a,b; Okorie et al., 2007; NRC, 2011).

Secondly, a high crude protein with low energy usually reduces the protein utilization efficiency and causes unnecessary feed costs coupled with adverse environmental impacts (Catacutan \& Coloso, 1995; Tibbetts et al., 2000; Alam et al., 2008). Thus, to overcome these problems, it is necessary to focus on improving the utilization of protein in order to avoid the supplementation of high levels of this nutrient in fish diets (Moreira et al., 2008).

\section{CONCLUSIONS}

The use of high crude protein contents with insufficient energy makes the diets unbalanced, which may result in the determination of improper dietary protein and energy requirements coupled with increased feed costs and aquatic pollution. Future studies should be focused on improving the dietary protein quality, according to the principles of diet-dilution technique and use of proper protein to energy ratios in order to formulate balanced diets. This information may provide an excellent framework to establish bio-economically viable and environment-friendly diets in the aquaculture sector.

\section{ACKNOWLEDGMENTS}

The World Academy of Sciences (TWAS) and the Brazilian National Council for Scientific and Technological Development (CNPq) are acknowledged for providing a Ph.D. scholarship (190123/2014-1) to the first author. We also thank the São Paulo State Research Foundation (FAPESP).

\section{REFERENCES}

Abboudi, T., Ooghe, W., Larondelle, Y. \& Rollin, X. 2007. Determination of the threonine requirement for maintenance in Atlantic salmon (Salmo salar L.) fry with the diet dilution procedure. Aquaculture Nutrition, 13: 281-290.

Abimorad, E.G. \& Carneiro, D.J. 2007. Digestibility and performance of pacu (Piaractus mesopotamicus) juveniles - fed diets containing different protein, lipid and carbohydrate levels. Aquaculture Nutrition, 13: 19.

Ai, Q., Mai, K., Li, H., Zhang, C., Zhang, L., Duan, Q., Tan, B., Xu, W., Ma, H., Zhang, W. \& Liufu, Z. 2004. Effects of dietary protein to energy ratios on growth and body composition of juvenile Japanese seabass, Lateolabrax japonicus. Aquaculture, 230: 507-516.

Alam, M.S., Watanabe, W.O. \& Carroll, P.M. 2008. Dietary protein requirements of juvenile black sea bass, Centropristis striata. Journal of the World Aquaculture Society, 39: 656-663.

Ali, M.Z. \& Jauncey, K. 2005. Approaches to optimizing dietary protein to energy ratio for African catfish, 
Clarias gariepinus (Burchell, 1822). Aquaculture Nutrition, 11: 95-101.

Amoah, Y.T. 2012. Effect of dietary protein levels on growth and protein utilization in juvenile arctic char (Salvelinus alpinus). United Nations University, Fisheries Training Programme, Final Project, Iceland. [http://www.unuftp.is/static/fellows/document/yaa11p rf.pdf]. Reviewed: 10 March 2018.

Bicudo, A.J.A., Sado, R.Y. \& Cyrino, J.E.P. 2010. Growth and hematology of pacu, Piaractus mesopotamicus, fed diets with varying protein to energy ratio. Aquaculture Research, 40: 486-495.

Campbell, R.G., Taverner, M.R. \& Curic, D.M. 1985. The influence of feeding level on the protein requirement of pigs between 20 and $45 \mathrm{~kg}$ live weight. Animal Production Science, 40: 489-496.

Carter, C.G., Owen, S.F., He, Z-Y., Watt, P.W., Scringeour, C., Houlihan, D. \& Rennie, M. 1994. Determination of protein synthesis in rainbow trout, Oncorhynchus mykiss, using a stable isotope. Journal of Experimental Biology, 189: 279-284.

Catacutan, M.R. \& Coloso, R.M. 1995. Effect of dietary protein to energy ratios on growth, survival, and body composition of juvenile Asian seabass, Lates calcarifer. Aquaculture, 131: 125-133.

Chaitanawisuti, N., Rodruang, C. \& Siyatiratitivorakul, P. 2010. Optimum dietary protein levels and protein to energy ratios on growth and survival of juveniles spotted babylon (Babylonia areolata Link) under the recirculating seawater conditions. International Journal of Fisheries and Aquaculture, 2(2): 58-63.

Chi, S.Y, Zhou, Q.C., Tan, B.P., Dong, X.H., Yang, Q.H. \& Zhou, J.B. 2010. Effect of dietary protein and lipid levels on growth performance, carcass composition, and digestive enzymes of the juvenile spotted babylon, Babylonia areolata Link 1807. Journal of the World Aquaculture Society, 41(6): 1-9.

Cho, C.Y. 1992. Feeding systems for rainbow trout and other salmonids concerning current estimates of energy and protein requirements. Aquaculture, 100: 107-123.

Cho, S.H., Lee, S.M., Lee, S.M. \& Lee, J.H. 2005. Effect of dietary protein and lipid levels on growth and body composition of juvenile turbot (Scophthalmus maximus L.) reared under optimum salinity and temperature conditions. Aquaculture Nutrition, 11: 235-240.

Cowey, C.B. 1992. Nutrition: estimation requirements of rainbow trout. Aquaculture, 100: 177-189.

Das, K.M., Mohanty, S. \& Sarkar, S. 1991. Optimum dietary protein to energy ratio for Labeo rohita fingerlings. In: Silva, S. (Ed.). Fish nutrition research in Asia. Proceedings of the Fourth Asian Fish Nutrition Workshop. Asian Fisheries Society, Manila, pp. 69-74.

Ekmann, K.S., Dalsgaard, A.J.T., Holm, J., Campbell, P.J. \& Skov, P.V. 2013. Effects of dietary energy density and digestible protein: energy ratio on de novo lipid synthesis from dietary protein in gilthead sea bream (Sparus aurata) quantified with stable isotopes. British Journal of Nutrition, 110: 1771-1781.

El-Mowafi, A., Ruohonen, K., Hevroy, E.M. \& Espe, M. 2010. Impact of digestible energy levels at three different dietary amino acid levels on growth performance and protein accretion in Atlantic salmon. Aquaculture Research, 4: 373-384.

El-Sayed, A.M. \& Teshima, S. 1992. Protein and energy requirements of Nile tilapia, Oreochromis niloticus, fry. Aquaculture, 103: 55-63.

Fernandes, J.P.C.L. 2013. Optimizing the dietary protein: lipid ratio on meagre (Argyrosomus regius): effects on growth and lipid deposition. Dissertação, Mestrado em Ecologia Marinha, University of Lisbon, Lisbon, 46 pp.

Fernandes, J.B.K., Carneiro, D.J. \& Sakomura, N.K. 2000. Sources and levels of crude protein in diets for pacu (Piaractus mesopotamicus) fingerlings. Revista Brasileira de Zootecnia, 29(3): 646-653.

Fernandes, J.B.K., Carneiro, D.J. \& Sakomura, N.K. 2001. Sources and levels of crude protein in diets for pacu (Piaractus mesopotamicus) juveniles. Revista Brasileira de Zootecnia, 30(3): 617-626.

Fisher, C. \& T.R. Morris. 1970. The determination of the methionine requirement of laying pullets by a diet dilution technique. Revista Brasileira de Zootecnia, 11: 67-82.

Freeman, C.P. 1979. The tryptophan requirement of broiler chicks. Revista Brasileira de Zootecnia, 20: 27 37.

Garling, D.I. \& Wilson, R.P. 1976. Optimum dietary protein to energy ratio for channel catfish, Ictalurus punctatus fingerlings. Jornal of Nutrition, 106: 13681375.

Gous, R.M. \& Morris, T.R. 1985. Evaluation of a diet dilution technique for measuring the response of broiler chickens to increasing concentrations of lysine. Revista Brasileira de Zootecnia, 26(2): 147-161.

Gous, R.M., Faulkner, A.S. \& Swatson, H.K. 2018. The effect of dietary energy: protein ratio, protein quality and food allocation on the efficiency of utilization of protein by broiler chickens. Revista Brasileira de Zootecnia, 59(1): 100-109.

Gous, R.M., Emmans, G.C., Broadbent, L.A. \& Fisher, C. 1990. Nutritional effects on the growth and fatness of broilers. Revista Brasileira de Zootecnia, 31: 495-505. 
Halver, J.E. \& Hardy, R.W. 2002. Fish nutrition. Academic Press, San Diego.

Hauler, R.C. \& Carter, C.G. 2001. Lysine deposition responds linearly to marginal lysine intake in Atlantic salmon (Salmo salar L.) parr. Aquaculture Research, 32(1): 147-156.

Hepher, B. 1988. Nutrition of pond fishes. Cambridge University Press, Sydney.

Hernández, M.D., Egea, M.A., Martínez, F.J., Rueda, F.M., Aguado, F. \& García, B. 2001. Effects of commercial diets with different $\mathrm{P} / \mathrm{E}$ ratios on sharp snout seabream (Diplodus puntazzo) growth and nutrient utilization. Aquaculture, 195: 321-329.

Hillestad, M. \& Johnsen, F. 1994. High energy low protein diets for Atlantic salmon - effects on growth, nutrient retention, and slaughter quality. Aquaculture, 124: 109-116.

Kesamura, K., Okumura, N., Takeda, H. \& Kuroki, A. 1982. Studies on the nutrition of tilapia nilotica. 3. Protein requirement of fingerling tilapia nilotica. Bulletin of the Faculty of Agriculture, Miyazaki University, 29: 285-291.

Kim, K., Moniruzzaman, M., Kim, K., Han, H.S., Yun, H., Lee, S. \& Bai S. 2016a. Effects of dietary protein levels on growth performance and body composition of juvenile parrot fish, Oplegnathus fasciatus. International Aquatic Research, 8(3): 239-245.

Kim, K., Moniruzzaman, M., Kim, K., Han, H.S., Yun, H., Lee, S. \& Bai S. 2016b. Re-evaluation of the optimum dietary protein level for maximum growth of juvenile barred knifejaw, Oplegnathus fasciatus reared in cages. Fisheries and Aquatic Sciences, 19: 24.

Kim, K.W., Wang, X.J., Han, K., Bai, S.C. \& Kang, J.C. 2004. Optimum dietary protein level and protein-toenergy ratio for the growth of juvenile Korean rockfish, Sebastes schlegeli. Journal of the World Aquaculture Society, 35(3): 305-314.

Kim, L.O. \& Lee, S-M. 2005. Effects of the dietary protein and lipid levels on growth and body composition of bagrid catfish, Pseudobagrus fulvidraco. Aquaculture, 243: 323-329.

Kyriazakis, I. \& Emmans, G.C. 1992. The effects of varying protein and energy intakes on the growth and body composition of pigs: 2 . The effects of varying both energy and protein intake. British Journal of Nutrition, 68: 615-625. doi.org/10.1079/BJN19920120

Lee, S.M., Jeon, I.G. \& Lee, J.Y. 2002. Effects of digestible protein and lipid levels in practical diets on growth, protein utilization and body composition of juvenile rockfish (Sebastes schlegeli). Aquaculture, 80(5): 227-239.

Lemos, M.V.A., Arantes, T.Q., Souto, C.N., Martins, G.P., Araújo, J.G. \& Guimarães, I.G. 2014. Effects of digestible protein to energy ratios on growth and carcass chemical composition of Siamese fighting fish (Betta splendens). Ciência e Agrotecnologia, 38(1): 76-84.

Li, X., Jiang, Y. \& Liu, W. 2012. Protein-sparing effect of dietary lipid in practical diets for blunt snout bream (Megalobrama amblycephala) fingerlings: effects on digestive and metabolic responses. Fish Physiology and Biochemistry, 38(2): 529-541.

Li, Y., Bordinhon, A.M., Davis, D.A., Zhang, W. \& Zhu, X. 2013. Protein: energy ratio in practical diets for Nile tilapia, Oreochromis niloticus. Aquaculture International, 21(5): 1109-1119.

Liebert, F. \& Benkendorff, K. 2007. Modeling lysine requirements of Oreochromis niloticus due to principles of the diet dilution technique. Aquaculture, 267: $100-110$.

Lovell, R.T. 1989. Nutrition and feeding of fish. Van Nostrand Reinhold, New York.

Lupatsch, I., Kissil, G.W., Sklan, D. \& Pfeffer, E. 1998. Energy and protein requirements for maintenance and growth in gilthead seabream (Sparus aurata L.). Aquaculture Nutrition, 4: 165-173.

Martino, R.C., Cyrino, J.E.P., Portz, L. \& Trugo, L.C. 2002a. Effect of dietary lipid level on nutritional performance of the surubim, Pseudoplatystoma coruscans. Aquaculture, 209: 209-218.

Martino, R.C., Cyrino, J.E.P., Portz, L. \& Trugo, L.C. 2002b. Performance and fatty acid composition of surubim (Pseudoplatystoma coruscans) fed diets with animal and plant lipids. Aquaculture, 209: 233-246.

McGoogan, B.B. \& Gatlin, D.M. 1999. Dietary manipulations affecting growth and nitrogenous waste production of red drum, Sciaenops ocellatus: I. Effects of dietary protein and energy levels. Aquaculture, 178: 333-348.

Mohseni, M., Pourkazemi, M., Hosseni, M.R., Hassani, M.H.S. \& Bai, S.C. 2013. Effects of the dietary protein levels and the protein to energy ratio in sub-yearling Persian sturgeon, Acipenser persicus (Borodin). Aquaculture Research, 44: 378-387.

Moon, H.Y. \& Gatlin, D.M. 1991. Total sulfur amino acid requirement of juvenile red drum, Sciaenops ocellatus. Aquaculture, 95: 97-106.

Moreira, I.S., Peres, H., Couto, A., Enes, P. \& OlivaTeles, A. 2008. Temperature and dietary carbohydrate level effects on performance and metabolic utilization of diets in European sea bass (Dicentrarchus labrax) juveniles. Aquaculture, 274: 153-160.

Morris, T.R. \& Njuru, D. 1990. Protein requirement of fast- and slow-growing chicks. Revista Brasileira de Zootecnia, 31: 803-809. 
Morris, T.R., AL-Azzawi, K., Gous, R.M. \& Simpson, G.L. 1987. Effects of protein concentration on responses to dietary lysine by chicks. Revista Brasileira de Zootecnia, 28: 185-195.

Nankervis, L., Matthews, S.J. \& Appleford, P. 2000. Effect of dietary non-protein energy source on growth, nutrient retention and circulating insulin-like growth factor I and triiodothyronine levels in juvenile barramundi, Lates calcarifer. Aquaculture, 191: 323335.

National Research Council (NRC). 2011. Nutrient requirements of fish. National Academy Press, Washington D.C.

Okorie, E.O., Kim, Y.C., Lee, S., Bae, J.Y., Yoo, J.H., Han, K., Bai, S.C., Park, G. \& Choi, S. 2007. Reevaluation of the dietary protein requirements and optimum dietary protein to energy ratios in Japanese eel, Anguilla japonica. Journal of the World Aquaculture Society, 38: 418-426.

Pilbrow, P.J. \& Morris, T.R. 1974. Comparison of lysine requirements amongst eight stocks of laying fowls. Revista Brasileira de Zootecnia, 15: 51-73.

Rahim, A., Abbas, G., Ferrando, S., Gallus, L., Ghaffar, A., Mateen, A., Hafeez-ur-Rehman, M. \& Waryani, B. 2016. Effects of varying dietary protein level on growth, nutrient utilization and body composition of juvenile blackfin sea Bream, Acanthopagrus berda (Forsskal, 1775). Pakistan Journal of Zoology, 48(4): 1089-1097.

Riche, M. 2009. Evaluation of digestible energy and protein for growth and nitrogen retention in juvenile Florida pompano, Trachinotus carolinus. Journal of the World Aquaculture Society, 40(1): 1-13.

Robinson, E.H. \& Li, M.H. 1997. Low protein diets for channel catfish, Ictalurus punctatus raised in earthen ponds at high density. Journal of the World Aquaculture Society, 28(3): 224-229.

Santiago, C. \& Laron, M. 1991. Growth response and carcass composition of red tilapia fry fed diets with varying protein and protein to energy ratios. In: Silva, S. (Ed.). Fish nutrition research in Asia. Proceedings of the Fourth Asian Fish Nutrition Workshop. Asian Fisheries Society, Manila, p. 55-62.

Shiau, S.Y. \& Lan, C.W. 1996. Optimum dietary protein level and protein to energy ratio for growth of grouper (Epinephelus malabaricus). Aquaculture, 145: 259266.

Siddiqui, A.Q., Howlader, M.S. \& Adams, A.A. 1988. Effect of dietary protein level on growth, feed conversion and protein utilization in fry and young tilapia niloticus. Aquaculture, 70: 63-73.

Silva, S.S.D. \& Perera, P.A.B. 1985. Effects of dietary protein level on growth and feed conversion and protein use in young tilapia nilotica at four salinities.
Transactions of the American Fisheries Society, 114: 685-689.

Souto, C.N., Lemos, M.V.A., Martins, G.P., Araújo, J.G., Almeida, K.L., Lopes, M. \& Guimarães, I.G. 2013. Protein to energy ratios in goldfish (Carassius auratus) diets. Ciência e Agrotecnologia, 37(6): 550558.

Tacon, A.G. \& Cowey, C.B. 1985. Protein and amino acid requirement. In: Tytler, P. \& Calow, P. (Eds.). Fish energetic: new perspectives. Croom Helm, London, pp. 155-183.

Teshima, S., Kanazawa, A. \& Uchiyama, Y. 1985. Effects of dietary protein, lipid, and digestible carbohydrate levels on the weight gain, feed conversion efficiency and protein efficiency ratio of Tilapia nilotica. Memoirs of the Kagoshima University, Research Center for the South Pacific Islands, 6: 56-71.

Tibbetts, S.M., Lall, S.P. \& Anderson, D.M. 2000. Dietary protein requirement of juvenile American eel (Anguilla rostrata) fed practical diets. Aquaculture, 186: $145-155$.

Vásquez-Torres, W., Filho, M.P. \& Arias-Castellanos, J.A. 2011. Studies for composition of semi purified reference diet for nutritional requirements evaluation of juvenile pirapitinga, Piaractus brachypomus (Cuvier, 1818). Revista Brasileira de Zootecnia, 31: 283-292.

Veras, G.C., Salaro, A.L., Zuanon, J.A.S., Carneiro, A.P.S., Campelo, D.A.V. \& Murgas, L.D.S. 2010. Growth performance and body composition of giant trahira fingerlings fed diets with different protein and energy levels. Pesquisa Agropecuária Brasileira, 45(9): 1021-1027.

Walton, M.J. \& Cowey, C.B. 1982. Aspects of intermediary metabolism in fish. Comparative Biochemistry and Physiology, Part B, 73: 59-79.

Wang, K., Takeuchi, T. \& Watanabe, T. 1985a. Effect of dietary protein levels on growth of tilapia nilotica. Bulletin of the Japanese Society for the Science of Fish, 51: 133-140.

Wang, K., Takeuchi, T. \& Watanabe, T. 1985b. Optimum protein and digestible energy levels in diets for tilapia nilotica. Bulletin of the Japanese Society for the Science of Fish, 51: 141-146.

Wang, Y.Y., Ma, G.J., Shi, Y., Liu, D.S., Guo, J.X., Yang, Y.H. \& Chen, C.D. 2013. Effects of dietary protein and lipid levels on growth, feed utilization and body composition in Pseudobagrus ussuriensis fingerlings. Aquaculture Nutrition, 19(3): 390-398.

Webster, C.D., Tiu, L.G., Tidwell, J.H., Wyk, P.V. \& Howerton, R.D. 1995. Effects of dietary protein and lipid levels on growth and body composition of 
sunshine bass (Morone chrysops $\times$ Morone saxatilis) reared in cages. Aquaculture, 131(1): 291-301.

Wethli, E., Morris, T.R. \& Shresta, T.P. 1975. The effect of feeding high levels of low-quality proteins too growing chickens. British Journal of Nutrition, 34: 363-373.

Received: 8 August 2018; Accepted: 13 November 2018
Winfree, R.A. \& Stickney, R.R. 1981. Effects of dietary protein and energy on growth feed conversion efficiency and body composition of Tilapia aurea. Journal of Nutrition, 111(6): 1001-1012.

Zuanon, J.A.S., Salaro, A.L., Moraes, S.S.S., Alves, L.M.D., Balbino, E.M. \& Araújo, E.S. 2009. Dietary protein and energy requirements of juvenile freshwater angelfish. Revista Brasileira de Zootecnia, 38(6): 989993. 